\title{
UPAYA GURU DALAM MENYIKAPI PERGESERAN PERILAKU SISWA DALAM PERSPEKTIF NILAI-NILAI BUDAYA BANGSA DI SMP NEGERI 18 KOTA CIREBON
}

\author{
Selvia $^{1}$, Yeti Nurizzati ${ }^{2}$ \\ IAIN Syekh Nurjati Cirebon ${ }^{1,2}$ \\ selvy.bae16@gmail.com; yeti@syekhnurjati.ac.id
}

\begin{abstract}
Abstrak
Penelitian ini di latar belakangi karena Indonesia merupakan negara yang memiliki beragam kebudayaan, Indonesia juga telah dikenal luas di mata dunia dengan budaya yang menjunjung tinggi keramahan, dan sopan santun. Nilai-nilai budaya dan karakteristik masyarakat Indonesia yang sangat kental dengan perilakunya yang santun, menjunjung tinggi gotong- royong, saling menghormati, dan menghargai orang lain terlebih dengan orang yang lebih tua. Namun, seiring berjalannya pengaruh globalisasi dan modernisasi bergeser pula perilaku dalam nilai- nilai budaya kebangsaan yang telah diwariskan oleh nenek moyang kita yaitu berupa perilaku dan berbahasa santun pada orang lain terlebih pada orang yang lebih tua. Hal ini dapat terlihat dari siswa yang melawan terhadap bapak dan ibu guru, melanggar peraturan sekolah dan berbahasa yang tidak sopan. Contoh melotot pada saat diberikan perintah dan berbahasa yang tidak sopan terhadap bapak dan ibu guru. Jenis penelitian adalah penelitian kualitatif dengan metode studi kasus dalam etnografi. Pengumpulan data yang digunakan dalam penelitian adalah observasi, wawancara dan dokumentasi. Teknik analisis data yang digunakan yaitu triangulasi. Subjek penelitian meliputi guru dan siswa SMP Negeri 18 Kota Cirebon. Hasil penelitian menunjukan bahwa, terdapat pergeseran perilaku siswa dalam perspektif nilai-nilai budaya bangsa di SMP Negeri 18 Kota Cirebon. Faktor-faktor yang mempengaruhi pergeseran perilaku siswa yaitu faktor keluarga, faktor minim pendidikan orang tua, dan faktor perkembangan teknologi atau media massa. Dalam menyikapi pergeseran perilaku siswa di SMP 18 Kota Cirebon guru melakukan mengawasan, kerjasama dengan orang tua, hukuman/sanksi dan pembinaan mental melalui program-program yang religius. Dari hasil penelitian ini diharapkan para siswa menyadari pentingnya nilai-nilai budaya bangsa dan mengaplikasikanya sehingga diharapkan siswa memiliki perilaku yang lebih baik.
\end{abstract}

Kata kuci : Perilaku, Bahasa, Budaya Bangsa

\begin{abstract}
This research in the background because Indonesia is a country that has a variety of cultures, Indonesia has also been widely known in the eyes of the world with a culture that uphold friendliness, and courtesy. Cultural values and characteristics
\end{abstract}


of Indonesian society are very strong with polite behavior, uphold mutual cooperation, mutual respect, and respect others especially with older people. However, as the influence of globalization and modernization shifted also behavior in the values of national culture that has been inherited by our ancestors in the form of behavior and language to other people, especially in the older people. This can be seen from students who are against the father and mother of the teacher, violating school rules and abusive language. Examples of glaring at the time given commands and language that is not polite to the father and mother teacher. The type of research is qualitative research with case study method in ethnography. Data collection used in this research are observation, interview and documentation. Data analysis technique used is triangulation. Research subjects include teachers and students of SMP Negeri 18 Kota Cirebon. The results showed that, there is a shift in student behavior in the perspective of cultural values of the nation in SMP Negeri 18 Kota Cirebon. Factors that influence student behavior shift are family factor, parental education minimal factor, and technological development factor or mass media. In responding to the shift behavior of students in SMP Negeri 18 Kota Cirebon teachers do supervision, cooperation with parents, penalties / sanctions and mental coaching through religious programs. From the results of this study is expected students realize the importance of cultural values of the nation and apply so that students are expected to have better behavior.

Keywords: Behavior, Language, Culture Nation

\section{A. PENDAHULUAN}

1. Latar Belakang Masalah

Indonesia merupakan negara yang memiliki beragam kebudayaan, Indonesia juga telah dikenal luas di mata dunia dengan budaya yang menjunjung tinggi keramahan, dan sopan santun. Nilai-nilai budaya dan karakteristik masyarakat Indonesia yang sangat kental dengan perilakunya yang santun, menjunjung tinggi gotong- royong, saling menghormati, dan menghargai orang lain terlebih dengan orang yang lebih tua.

Masyarakat telah bergerak kearah yang semakin maju dan modern. Setiap perubahan masyarakat akan melahirkan konsekuensi-konsekuensi tertentu yang berkaitan dengan nilai dan moral. Misalnya kemajuan dibidang teknologi komunikasi melahirkan pergeseran budaya belajar anak-anak dan benturan antara tradisi budaya barat yang bebas dengan tradisi timur yang penuh keterbatasan norma demikian pula dampaknya 
pada nilai-nilai budaya termasuk tata cara dan perilaku di kalangan generasi muda. Dalam kondisi ini, pendidik (khususnya sekolah) dituntut untuk memiliki kemampuan mendidik dan mengembangkan etika prilaku santun.

Sesuai dengan Undang-Undang Sistem Pendidikan Nasional (pasal 1 UU No. 20 Th. 2003) dinyatakan bahwa pendidikan adalah usaha sadar dan terencana untuk mewujudkan suasana belajar dan proses pembelajaran agar siswa secara aktif mengembangkan potensi dirinya untuk memiliki kekuatan spiritual keagamaan, pengendalian diri, kepribadian, kecerdasan, masyarakat, bangsa dan negara.

Dewasa ini, kalangan remaja lebih menyukai budaya dengan bahasa dan berperilaku yang kebarat-baratan, bahasa dan berperilaku tersebut merupakan hal yang dirasa keren hingga budaya ketimuran jarang diaplikasikan lagi pada remaja saat ini khususnya pada siswa SMP Negeri 18 kota Cirebon sehingga bergeser nilai-nilai budaya bangsa ketimuran yang selama ini dipelajari dan dianut dari budaya leluhur. Sebagai contoh, sekolah merupakan institusi pendidikan yaitu tempat di mana pendidikan berlangsung. Namun masih banyak siswa yang tidak lagi memiliki bahasa dan perilaku santun terlebih kepada guru, image guru saat ini tidak lagi sebagai panutan. Padahal pada hakikatnya seorang siswa harus hormat dan berperilaku sopan terhadap gurunya.

Berdasarkan hasil pengamatan yang dilakukan peneliti di SMP N 18 Kota Cirebon. Pada kenyataan di lapangan ditemukan masalah mengenai karakter siswa, yang mengalami pergeseran budaya berupa perilaku sopan santun yang menyimpang terhadap guru maupun orang tua. Hal ini dapat terlihat dari siswa yang melawan terhadap bapak dan ibu guru, melanggar peraturan sekolah dan berbahasa yang tidak sopan. Contoh melotot pada saat diberikan perintah dan berbahasa yang tidak sopan terhadap bapak dan ibu guru.

Berdasarkan pemaparan di atas, penelitian ini perlu dikaji lebih dalam lagi, tentang pergeseran perilaku pada siswa di SMP N 18 Kota 
Cirebon yang melawan terhadap Bapak atau Ibu guru, melanggar peraturan sekolah dan berbahasa yang tidak sopan.

Berangkat dari masalah di atas peneliti tertarik untuk melakukan penelitian dengan judul “Upaya Guru dalam Menyikapi Pergeseran Perilaku Siswa dalam Persepetif Nilai-Nilai Budaya Bangsa di SMP Negeri 18 Kota Cirebon.

2. Rumusan Masalah

Berdasarkan fokus kajian yang peneliti kemukakan di atas, maka rumusan masalah tersebut sebagai berikut:

a. Bagaimana pergeseran perilaku siswa dalam perspektif nilai-nilai budaya bangsa di SMP Negeri 18 Kota Cirebon?

b. Bagaimana guru menyikapi adanya pergeseran perilaku dan bahasa pada siswa di SMP Negeri 18 Kota Cirebon?

c. Faktor- faktor apa saja yang mempengaruhi adanya pergeseran perilaku siswa dalam perspektif nilai- nilai budaya bangsa berupa perilaku dan bahasa pada siswa di SMP Negeri 18 Kota Cirebon?

3. Tujuan Penelitian

Berdasarkan rumusan masalah tersebut, maka tujuan dilakukannya penelitian ini adalah sebagai berikut:

a. Mendeskripsikan bagaimana pergeseran perilaku siswa dalam perspektif nilai-nilai budaya bangsa di SMP Negeri 18 Kota Cirebon.

b. Mendeskripsikan bagaimana guru menyikapi adanya pergeseran perilaku dan bahasa pada siswa di SMP Negeri 18 Kota Cirebon

c. Mendeskripsikan faktor apa saja yang mempengaruhi adanya pergeseran nilai- nilai budaya bangsa berupa perilaku dan bahasa di SMP Negeri 18 Kota Cirebon.

\section{B. KAJIAN TEORI}

1. Perilaku

a. Pengertian Perilaku

Krech, Crutchfield dan Ballechey (1982)dalam Rusli Ibrahim(2001: 8), perilaku sosial seseorang itu tampak dalam pola 
respon antar orang yang dnyatakan dengan hubungan timbal balik antara pribadi. Perilaku sosial juga identik dengan reaksi seseorang terhadap orang lain.

Baron dan Byrne, 1991 dalam Ibrohim(2001: 12), perilaku itu ditunjukan dengan perasaan, tindakan, sikap keyakinan, kenangan, atau rasa hormat terhadap orang lain. Perilaku sosial seseorang merupakan sikap relative untuk menanggapi orang lain dengan caracara yang berbeda. Misalnya dalam melakukan kerjasama, ada orang yang mealakukan dengan tekun, sabar, dan selalu mementingkan kepentingan bersama di atas kepentingan peribadinya. Sementara di pihak lain ada orang yang bermalas-malasan, tidak sabaran dan hanya ingin mencari untung sendiri.

b. Nilai -nilai budaya bangsa

Nilai nilai budaya mencerminkan hasil budaya Indonesia yang berlandaskan Pancasila dan Undang Undang Dasar 1945, yang berposes menuju terwujudnya kualitas manusia Indonesia dan kualitas masyarakat Indonesia.

Penjelasan Undang-Undang Dasar 1945 memberikan rumusan tentang kebudayaan yang timbul sebagi buah usaha budidaya rakyat Indonesia seluruhnya termasuk kebudayaan lama dan asli yang terdapat sebagai puncak-puncak kebudayaan di daerah- daerah di seluruh Indonesia terhitung sebagi kebudayaan nasional. Usaha kebudayaan harus menuju kearah kemajuan adab, budaya dan persatuan, dengan tidak menolak bahan-bahan baru dari kebudayaan asing yang dapat memperkembangkan atau memperkaya kebudayaan bangsa sendiri, serta mempertinggi derajat kemanusiaan bangsa Indonesia. (Ranjabar, 2010 : 60-61)

2. Kajian Penelitian yang Relevan

Hasil penelitian yang dilakukan Nur Cahyaningsih (2017) tentang Pembinaan Sikap Sopan Siswa Terhadap Guru di MTS Negeri I Rakit Kecamatan Rakit Kabupaten Banjarnegara. Berdasarkan penelitian tersebut pembinaan sikap sopan dilakukan guru yaitu sikap sopan dalam 
berbahasa, sopan santun dalam berperilaku, sopan santun dalam berpakaian.

a. Persamaan

Persamaan antara penelitian yang dilakukan oleh Nur Cayaningsih dengan penelitian ini adalah mengkaji tentang sikap atau perilaku siswa.

b. Perbedaan

Perbedaannya yaitu jika penelitian yang dilakukan oleh Nur Cayaningsih adalah hanya meneliti tentang pembinaan sikap sopan tetapi penelitian yang akan peneliti lakukan yaitu mengkaji tentang pergeseran perilaku siswa dalam perspektif nilai-nilai budaya bangsa

\section{METODOLOGI}

1. Jenis Penelitian

Penelitian ini berbentuk deskriptif kualitatif dengan menggunakan metode studi kasus dalam etnografi. Dimana penelitian ini berusaha untuk menjawab pertanyaan sebagaimana di atas yaitu Pergeseran Perilaku Siswa dalam Perspektif Nilai-nilai Budaya Bangsa di SMP 18 Kota Cirebon. Penelitian kualitatif tidak mengutamakan besarnya populasi atau informan, bahkan populasi dan informan yang diambil sangat terbatas, karena sudah terfokuskan dengan masalah yang sudah ditentukan oleh peneliti. Jika data sudah mendalam dan cukup menjelaskan fenomena yang diteliti maka tidak perlu mencari informan lain. Menurut Bungin (2007: 68) penelitian deskriptif kualitatif bertujuan untuk menggambarkan, meringkas berbagai kondisi, fenomena, dan realitas sosial yang ada di lingkungan pendidikan yang menjadi objek penelitian.

2. Lokasi dan Waktu Penelitian

Tempat penelitian ini adalah SMP Negeri 18 Kota Cirebon. Jln. Pronggol No 19/ Lemah Wungkuk /Cirebon 45132 Jawa Barat Cirebon. Adapun waktu pelaksanaan penelitian dari bulan Januari - Maret 2018.

3. Sumber Data

Sumber data yang didapat dari sebagai berikut : 
a. Sumber data primer, yaitu data yang diperoleh secara langsung dari objek yang diteliti. Data ini dapat berupa hasil teks wawancara dan diperoleh melalui wawancara dengan informan yang sedang dijadikan sampel dalam penelitiannya.

b. Data primer dalam penelitian ini adalah data - data yang diperoleh dari orangtua (guru) dan siswa SMP Negeri 18 Kota Cirebon yang berperilaku baik maupun tidak baik. Sumber data sekunder, yaitu data tambahan berupa informasi yang akan melengkapi data primer. Data sekunder yang peneliti peroleh dari penelitian yang telah dilakukan antara lain:

1) Dokumen atau arsip dari SMP Negeri 18 Kota Cirebon.

2) Data sekunder lain yaitu dokumentasi berupa foto-foto yang peneliti hasilkan sendiri dengan kamera HP, catatan hasil wawancara yang diperoleh peneliti saat melakukan wawancara dengan subjek dan informan penelitian serta data-data lain yang dijadikan bahan tambahan untuk mendapatkan data objek penelitian.

4. Subyek Penelitian

Subyek penelitian terfokus pada Guru dan siswa SMP Negeri 18 Kota Cirebon.

5. Teknik dan Instrumen Pengumpulan Data

a. Observasi

Observasi yang dilakukan dalam hal ini, peneliti berkedudukan sebagai participant observer, yakni peneliti turut aktif pada waktu penelitian.

b. Wawancara

Responden atau informan wawancara dalam penelitian ini akan dilakukan dengan guru dan siswa SMP Negeri 18 kota Cirebon.

c. Dokumentasi

Metode dokumentasi ini dimaksudkan untuk memperoleh data berdasarkan sumber data yang ada di SMP Negeri 18 Kota Cirebon. 


\section{d. Triangulasi}

Triangulasi diartikan sebagai tehnik pengumpulan data yang bersifat mengabungankan dari berbagai tekhnik pengumpulan data dan sumber data yang telah ada.

6. Teknik Analisis Data

a. Pengumpulan data

Peneliti mencatat semua data secara objektif dan apa adanya sesuai dengan hasil observasi dan wawancara di lapangan.

b. Reduksi Data

Mereduksi data berarti merangkum, memilih hal-hal yang pokok, memfokuskan pada hal-hal yang penting dicari tema dan polanya dan membuang yang tidak perlu.

c. Display Data / Penyajian Data

Penyajian data berbentuk sekumpulan informasi yang tersusun sehingga dapat ditarik suatu kesimpulan. Penyajian data dilaksanakan agar sajian data tidak menyimpang dari pokok permasalahan.

d. Penarikan kesimpulan

Penarikan kesimpulan atau verifikasi adalah usaha untuk mencari atau memahami makna, keteraturan, pola-pola, penjelasan, alur sebab akibat atau proposisi. Verifikasi penulis lakukan setelah penyajian data selesai, dan ditarik kesimpulanya berdasarkan hasil penelitian lapangan yang telah dianalisis dengan teori.

7. Keabsahan Data

Menurut Moleong (2013: 321) Keabsahan data merupakan konsep penting dalam sebuah penelitian yang validitas dan realibilitasnya harus disesuaikan dengan tuntuntan pengetahuan. Keabsahan data dalam sebuah penelitian merupakan yang terpenting sebagai tolak ukur penelitian tersebut relevan antara teori dan permasalahan di lapangan.

\section{HASIL PENELITIAN DAN PEMBAHASAN}

Penelitian ini dilakukan untuk mengetahui pergeseran Perilaku Siswa dalam Perspektif Nilai-nilai Budaya Bangsa di SMP Negeri 18 Kota Cirebon 
Berdasarkan pengamatan pemaparan siswa-siswi di atas peneliti pahami bahwa banyaknya siswa yang melanggar peraturan tidak hanya dominan pada anak laki-laki saja melainkan banyak juga pelanggaran yang dilakukan oleh siswa perempuan, dari melanggar peraturan suka bolos, tidak masuk sekolah, melihat video yang tidak layak untuk ditonton, berkata kasar pada guru, bergurau ketika jam pelajaran berlangsung sampai dengan tawuran.

Berdasarkan hasil data-data yang terkait dengan pergeseran perilaku siswa dalam perspektif nilai-nilai budaya bangsa yang telah dipaparkan di atas maka jelas adanya pergeseran pada siswa di SMP Negeri 18 Kota Cirebon, hal ini dikuatkan dengan teoriBaron \& Byrne, 1991 dalam Ibrahim (2001: 12) yang mengemukakan, perilaku itu ditunjukan dengan perasaan, tindakan, sikap keyakinan, kenangan, atau rasa hormat terhadap orang lain.

Terkait dari teori di atas Baroon\& Byrne (1991) dalam Ibrahim (2001:15), mengatakan nilai-nilai perilaku sosial manusia yaitu santun, mampu bekerja sama, saling menghormati, tidak mengganggu hak orang lain, toleran dalam hidup bermasyaraka.

Dalam kaitannya dengan masalah pergeseran perilaku siswa di sekolah sudah semestinya perlu mendapat perhatian dan upaya menanggulanginya dari pihak sekolah baik lembaga maupun tenaga pengajar yang ada disekolah. Hal ini disebabkan karena sekolah merupakan lembaga pendidikan formal yang secara sengaja dirancang untuk melaksanakan pendidikan, dimana fungsinya diantaranya adalah untuk mempersiapkan anak didiknya sebagai individu, warga masyarakat, warga negara, dan warga dunia di masa depan yang berpengetahuan, berketerampilan, berkarakter dan berbudi luhur.

Menyikapi pergeseran perilaku siswa di SMP 18 Kota Cirebon sudah berjalan dengan baik karena pada dasarnya pihak sekolah baik Kepala Sekolah maupun guru-guru telah berusaha untuk memaksimalkan upaya sekolah dalam menanggulangi pergeseran perilaku pada siswa. Sejauh ini sekolah telah melakukan program-programnya yang berkaitan dengan masalah pergeseran perilaku siswa seperti mengontrol dan mengawasi perilaku siswa, menjalin kerjasama dengan orang tua dengan melakukan pemanggilan orang tua sampai home visit sebagai tindak lanjut terhadap anak- 
anak yang bermasalah, dan melakukan tindakan hukuman/sanksi yang tegas terhadap siswa yang melanggar peraturan. Selain itu sekolah juga melaksanakan kegiatan atau program-program keagamaan setiap hari seperti pembacaan Al-quran 15 menit sebelum pembelajaran berlangsung, siraman rohani pada hari Jum'at, dan selanjutnya yang terakhir pembinaan mental melalui siraman rohani yang diberikan oleh guru.

Sehubungan menindaklanjuti terkait Faktor-faktor apa saja yang mempengaruhi adanya pergeseran perilaku siswa dalam nilai- nilai budaya bangsa berupa perilaku dan bahasa pada siswa di SMP Negeri 18 Kota Cirebon dengan adanya pergeseran perilaku siswa faktor-faktor yang mempengaruhi pergeseran perilaku siswa dalam perspektif nilai-nilai budaya bangsa di SMP Negeri 18 Kota Cirebon yaitu dipengaruhi oleh faktor keluarga yang akhirnya berdampak pada psikolog siswa, lingkungan, faktor minim pendidikan orang tua, dan yang terakhir yaitu faktor perkembangan teknologi atau media massa.

Hal ini dikuatkan dalam teori Baron \& Byrne, 1991 dalam Ibrahim (2001: 14), yang berpendapat bahwa ada empat katogori utama yang membentuk perilaku sosial seseorang yaitu

\section{Perilaku Dan Karakteristik Orang Lain}

Jika seseorang lebih sering bergaul dengan orang-orang yang memiliki karakter santun, ada kemungkinan besar ia akan berperilaku seperti kebanyakan orang-orang berkarakter santun dalam lingkungan pergaulannya. Sebaliknya, jika ia bergaul dengan orang-orang yang berkarakter sombong, maka ia akan terpengaruh oleh perilaku seperti itu. Pada aspek ini guru memegang peranan penting sebagi sosok yang akan dapat mempengaruhi pembentukan perilaku sosial karena ia akan memberikan pengaruh yang cukup besar dalam mengarahkan siswa untuk melakukan sesuatu perbuatan.

2. Proses kognitif

Ingatan dan pikiran yang memuat ide-ide, keyakinan dan pertimbangan yang menjadi dasar kesadaran sosial seseorang akan berpengaruh terhadap perilaku sosialnya. Misalnya seorang calon pelatih yang terus berfikir kelak dikemudian hari menjadi pelatih yang baik, menjadi idola bagi atletnya dan 
orang lain akan terus berupaya, berproses mengembangkan, memperbaiki dirinya dan perilaku sosialnya.

3. Faktor lingkungan

Lingkungan alam terkadang dapat mempengaruhi perilaku sosial seseorang. Misalnya orang yang berasal dari daerah pantai atau pegunungan yang terbiasa berkata dengan keras, maka perilaku sosialnya seolah keras pula, ketika berbeda dilingkungan masyarakat yang terbiasa lembut dan halus dalam bertutur kata.

4. Tatar budaya sebagai tempat perilaku dan pemikiran sosial

Misalnya, seorang yang berasal dari etnis budaya tertentu mungkin akan terasa berperilaku sosial aneh ketika berada dalam lingkungan masyarakat yang beretnis budaya lain atau berbeda. Dalam konteks pembelajaran pendidikan yang terpenting adalah untuk saling menghargai perbedaan yang dimiliki oleh setiap anak.

Dari paparan di atas dapat disimpulkan bahwa banyak faktor yang mempengaruhi pergeseran perilaku siswa yang ada di SMP Negeri 18 Kota Cirebon. Seperti yang telah dijelaskan pada teori di atas, sudah berjalan dengan baik karena pada dasarnya pihak sekolah baik Kepala Sekolah maupun guru-guru telah berusaha untuk memaksimalkan upaya sekolah dalam menanggulangi pergeseran perilaku pada siswa. Sejauh ini sekolah telah melakukan program-programnya yang berkaitan dengan masalah pergeseran perilaku siswa seperti mengontrol dan mengawasi perilaku siswa, dan melakukan tindakan hukuman/sanksi yang tegas terhadap siswa yang melanggar peraturan.

\section{E. KESIMPULAN DAN SARAN}

a. Kesimpulan

Berdasarkan hasil analisis penelitian dan pembahasan yang telah dikemukakan, maka dapat ditarik kesimpulan sebagai berikut:

a. Terdapat Pergeseran perilaku pada siswa di SMP Negeri 18 Kota Cirebon, bersikap, berbahasa yang tidak sopan dan banyak yang melanggar peraturan sekolah. 
b. Faktor-faktor yang mempengaruhi pergeseran perilaku siswa dalam perspektif nilai-nilai budaya bangsa di SMP Negeri 18 Kota Cirebon yaitu dipengaruhi oleh faktor keluarga yang akhirnya berdampak pada psikolog siswa, lingkungan, faktor minim pendidikan orang tua, dan yang terakhir yaitu faktor perkembangan teknologi atau media massa.

c. Guru dalam menyikapi pergeseran perilaku siswa di SMP 18 Kota Cirebon sudah berjalan dengan baik karena pada dasarnya pihak sekolah baik Kepala Sekolah maupun guru-guru telah berusaha untuk memaksimalkan upaya sekolah dalam menanggulangi pergeseran perilaku pada siswa. Sejauh ini sekolah telah melakukan programprogramnya yang berkaitan dengan masalah pergeseran perilaku siswa seperti mengontrol dan mengawasi perilaku siswa, menjalin kerjasama dengan orang tua dengan melakukan pemanggilan orang tua sampai home visit sebagai tindak lanjut terhadap anak-anak yang bermasalah, dan melakukan tindakan hukuman/sanksi yang tegas terhadap siswa yang melanggar peraturan. Selain itu sekolah juga melaksanakan kegiatan atau program-program keagamaan setiap hari seperti pembacaan Al-quran 15 menit sebelum pembelajaran berlangsung, siraman rohani pada hari Jum'at, dan selanjutnya yang terakhir pembinaan mental melalui siraman rohani yang diberikan oleh guru.

2. Saran

Berdasarkan kesimpulan hasil penelitian di atas, penulis menyampaikan beberapa saran sebagai masukan, yang diharapkan dapat bermanfaat bagi semua pihak. Adapun sarannya yaitu:

a. Bagi Sekolah

Perlu adanya peningkatan dan berkelanjutan tentang program sekolah berbasis karakter baik yang bersifat intrakurikuler maupun ekstrakurikuler sehingga dapat mengembangkan potensi diri yang dimiliki siswa dalam rangka membantu proses tugas perkembangan nilai-nilai, sikap, moral dan perilaku yang diharapkan. 
b. Bagi Guru

Perlu adanya pendalaman aspek-aspek psikis dan kepribadian siswa secara teliti dan objektif, sehingga dengan demikian dapat dicegah kemungkinan kecenderungan munculnya pergeseran perilaku siswa. Guru sebagai panutan yaitu digugu dan ditiru diharapkan lebih meningkatkan kualitas pribadi guru agar dapat dicontoh para siswa, karena pendidikan tidak hanya dalam upaya mencapai nilai setinggitingginya akan tetapi berupaya juga untuk menciptakan peserta didik (manusia) berkarakter bangsa yang baik atau berbudi luhur dan bertanggung jawab.

c. Bagi Orang Tua Siswa

Hendaknya perlu menjalin kerjasama yang baik melalui komunikasi yang intensif kepada pihak sekolah dan guru, sehingga setiap permasalahan yang muncul pada diri siswa dapat ditanggulangi secara dini. Dengan demikian siswa bersangkutan akan terus dalam pengawasan baik di sekolah maupun di rumah.

d. Bagi Peneliti Lain

Perlu adanya penelitian lebih lanjut dan secara mendalam berkaitan dengan temuan penelitian ini, sehingga dapat membantu pihak sekolah dalam upaya menanggulangi pergeseran perilaku siswa.

\section{DAFTAR PUSTAKA}

Arikunto, Suharsimi. 2013. Prosedur Penelitian Pendekatan Suatu Praktik. Jakarta: Rineka Cipta.

Ali, muhammad. 2015. Psikologi Remaja. Jakarta : Bumi Aksara.

Al-Qusyairi, Syarif. 2009. Kamus Akbar Arab-. Surabaya : Giri Utama.

Azwar, Saifuddin. 2005. Sikap Manusia Teori dan Pengukuranya. Yogyakarta : Pustaka Pelajar.

Atif, Nurul Falah. 2010. Teori-teori Psikologi Sosial. Bandung : Rafika Aditama

Adisusilo, 2014. Pembelajaran Nilai-Karakter. Jakarta : Raja Grafinda Persada. 
Cahyaningsih, Nur. 2017. Pembinaan Sikap Sopan Siswa Terhadap Guru di MTs Negeri Rakit Kabupaten Banjar Negara. Skripsi. Purwokerto : Institut Agama Islam Negeri Purwokerto.

Darmodiharjo, Mardojo. Dkk. 2000. Santiaji Pancasial. Surabaya : Usana Offset Printing.

Depdiknas. 2016. Empat Pilar MPR RI. Jakarta : Sekretariat MPR RI.

Elmubarak, Zaim. 2008. Membumikan Pendidikan Nilai. Bandung : Alfabeta.

Herimanto. 2010. Ilmu Sosial dan Budaya Dasar. Jakarta Timur : Bumi Aksara.

Ibrahim, Rusli. 2001. Pembinaan Perilaku Sosial Melalui Pendidikan Jasmanai. Jakarta : Departemen Pendidikan Nasional.

J. Moleong, Lexy. 2010. Metodologi Penelitian Kualitatif. Bandung: Remaja Rosdakarya. 